
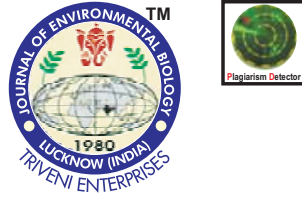

\title{
Effect of temperature regimes, seed priming and priming duration on germination and seedling growth on American cotton
}

Authors Info

K. Singh ${ }^{1 *}$, N. Gupta ${ }^{2}$ and M. Dhingra ${ }^{3}$

${ }^{1}$ Punjab Agricultural University Regional Research Station, Faridkot - 151 203, India

${ }^{2}$ Department of Plant Breeding and Genetics, Punjab Agricultural University, Ludhiana - 141 004, India

${ }^{3}$ Department of Soil Science, Punjab Agricultural University, Ludhiana - 141 004, India

${ }^{*}$ Corresponding Author Email : kulvir@pau.edu

Key words

Bt cotton hybrid

Seed priming

Hydropriming

Seedling growth

Publication Info

Paper received : 30.08.2016

Revised received : 05.01.2017

Re-revised received : 11.05.2017

Accepted : 24.06.2017

\section{Abstract}

Aim : High temperature during sowing of cotton results in poor emergence and high seedling mortality, thus leading to poor crop stand and reduced yield. Improvement in germination by seed priming may combat this problem as this physiological technique results in faster and synchronous seed germination. Hence, in vitro studies were conducted to evaluate the effect of different temperature regimes, seed priming and also duration of priming on germination and seedling growth to determine and exploit their usefulness in improving cotton seed germination for better seedling establishment.

Methodology : Seeds of Bt cotton hybrid (Ankur 3028 BGII) were primed separately with water and $\mathrm{KNO}_{3}$ at different concentrations $(2.5,5.0,7.5 \& 10.0 \%)$ for 2,4 and $6 \mathrm{hrs}$. Non-primed seeds and hydro primed seeds for $4 \mathrm{hrs}$ were considered as control. Seeds for each set of treatment were placed on moistened filter paper in petri dish. Each treatment was then divided into two sub-sets for assessment of seedling response at two temperature regimes i.e., at $25^{\circ} \mathrm{C}$ and at ambient temperature of $32-38.5^{\circ} \mathrm{C}$. After 7 days, final germination percentage, root length, shoot length and fresh weight of seedling were measured at both temperature regimes. Germination count was recorded on daily basis and was used to calculate speed of germination.

Results : Primed seeds exhibited an increase in germination by $43 \%$ and $34 \%$ than control (non-primed seeds) at ambient temperature $\left(32-38.5^{\circ} \mathrm{C}\right)$ and $25^{\circ} \mathrm{C}$ respectively. Germination speed also improved by $61 \%$ and $67 \%$ respectively at ambient temperature and $25^{\circ} \mathrm{C}$ over control. Hydropriming resulted in highest germination (75.5 and $79.2 \%$ ), germination speed (5.13 and 6.63 days), root length $(4.68$ and $6.30 \mathrm{~cm}$ ) and shoot length $(2.59$ and $3.40 \mathrm{~cm})$ than control at $25^{\circ} \mathrm{C}$ and ambient temperature respectively. Contrarily, increase in $\mathrm{KNO}_{3}$ concentration caused deleterious effects on root and shoot length.

Interpretation : Cotton seed germination was higher at ambient temperature $\left(32^{\circ}-38.5^{\circ} \mathrm{C}\right)$ than $25^{\circ} \mathrm{C}$ and priming improved germination potential of seeds. Hydropriming was more effective than $\mathrm{KNO}_{3}$ for enhancing germination percentage, germination speed and seedling growth at both temperature regimes. Studies concluded that hydro priming of cotton seeds improved germination, a key factor for better crop stand having positive effect on crop survival, and consequently improved cotton productivity.

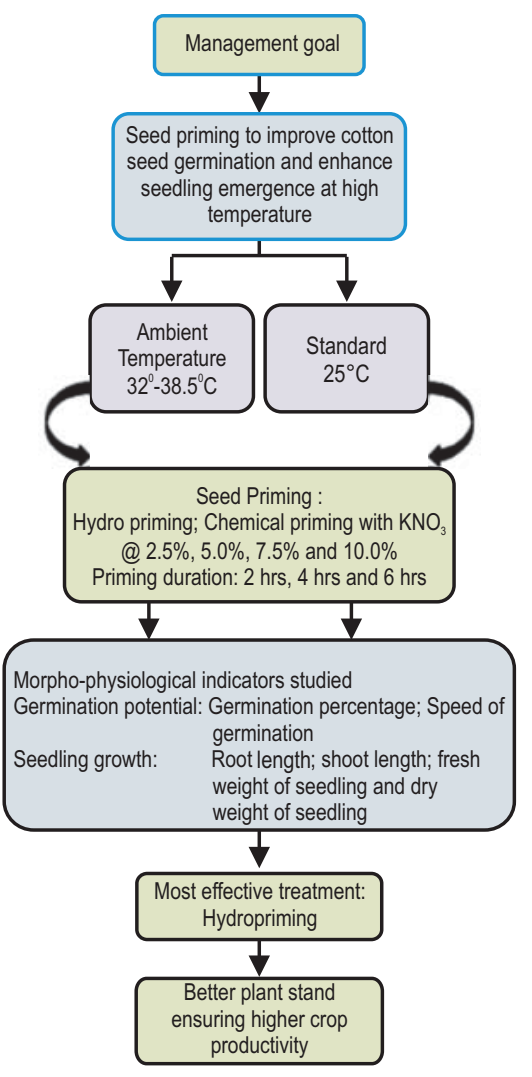




\section{Introduction}

Germination is the developmental stage that commences with water uptake and terminates with radicle emergence through seed coat. Imbibition in an essential part of germination process and is affected by various environmental factors including temperature (Kader and Jutzi, 2002). Rate of germination and its percentage are two main attributes of germination, affected by temperature significantly. Temperature can affect both of these attributes through at least three separate physiological processes viz., seed deterioration, loss of dormancy and germination process itself. Emergence is a function of both germination and early seedling growth, and delayed germination results in asynchronous emergence and poor stand establishment with negative consequences on crop survival and yield. North-western zone of India is characterized by brackish underground water and poor soil fertility. Here, cotton sown after pre-sowing irrigation with brackish underground water results in poor emergence owing to high sensitivity of germinating seed to accumulated salts in the soil. The situation is further deteriorated when such seedlings are exposed to continuous rising temperature often exceeding $40^{\circ} \mathrm{C}$, resulting in high mortality due to seedling burning (Singh et al., 2013a). Ultimately poor crop stand results in huge reduction in cotton yield. Seed priming is a cost effective technique which not only improves germination but also reduces seedling emergence duration and improves stand establishment. Ahmadvand et al. (2012a) observed rapid germination and emergence by seed priming technology along with improved seed establishment under stress conditions. Various seed priming techniques, have been developed in crop plants, which include hydro priming (soaking in water), halo priming (soaking in inorganic salt solutions i.e., $\mathrm{NaCl}, \mathrm{KNO}_{3}, \mathrm{CaCl}_{2}$ etc.), osmo priming (soaking in organic osmoticum like sugar, $\mathrm{PEG}$ etc.) and hormonal priming (soaking in different hormones like $\mathrm{GA}_{3}$, kinetin etc.) for improving germination and emergence. Priming technique provides controlled hydration of seeds to a level that allows initiation of metabolic activities involved in process of germination, but prevents the actual emergence of radicle and seeds can be dried back to initial moisture content, thus leading to faster germination of primed seeds than unprimed ones (Tilaki et al., 2010). A few reports on positive effects of potassium nitrate priming on seedling establishment have been demonstrated by Ahmadvand et al. (2012 a, b) and Cokkizgin and Bolek (2015). The effects of priming depend on many factors such as plant species, priming media, its concentration, priming duration, temperature and storage conditions etc. (Dorna et al., 2013). Hence, prior to field experimentation, generation of such basic information through laboratory experimentation is pre-requisite and of key importance. At present, no study is so far available that shows the quantitative effects of tested priming treatments (duration, priming agents and their different concentrations) under variable temperature regimes on germination and seedling growth of American cotton in North Indian context, though Singh et al. (2015) has reported some preliminary work. The purpose of the current study was that if something is found promising, it could be of great help in improving final germination. This would result in better vigor of cotton plants and reduced seedling mortality, particularly during initial sowing months which are too hot. The present study was intended for assessing the interactive effect of different temperature regimes, hydro and chemical priming at different durations and concentrations on germination behavior and seedling growth of $\mathrm{Bt}$ cotton to draw conclusive inferences.

\section{Materials and Methods}

The present study was carried out in two phases of experiments, arranged in a complete randomized design with three replications, during Kharif 2015. There were a total of 17 seed priming treatments. Seeds of Bt cotton hybrid (Ankur 3028 BGII) were used and studies were conducted in laboratory of Punjab Agricultural University, Regional Research Station, Faridkot. Initially, seeds were washed twice with distilled water and then primed according to different priming treatments. In first experiment, comparison of hydro primed seeds for different priming durations ( $2 \mathrm{hrs}, 4 \mathrm{hrs}$ and $6 \mathrm{hrs}$ ) and non-soaked seeds (non-primed/control) was done for assessing the effectiveness of priming. However in second experiment, seedling growth in response to chemical priming of $\mathrm{KNO}_{3}$ at different concentrations $(2.5 \%, 5.0 \%, 7.5 \%$ and $10.0 \%)$ and priming durations ( $2 \mathrm{hrs}, 4 \mathrm{hrs}$ and 6 hrs) was compared with 4 hrs hydroprimed seed as per recommended practice\} taken as control. Seed priming with $\mathrm{KNO}_{3}$ was achieved with a commercially available water soluble fertiliser by Coromandel company namely Gromor (N: P: K; 13:0:45). All priming operations were carried under controlled conditions at $25 \pm 1^{\circ} \mathrm{C}$ in dark growth chamber. After priming, samples of seeds were removed and washed thrice in distilled water. Seeds were then dried on a filter paper for 2-3 days under shade in a temperature range of $20-25^{\circ} \mathrm{C}$ to bring them back into their original moisture level (10 to $12 \%$ on dry weight basis). To study the effect of seed priming on germination and growth potential of seedlings, ten visually healthy and uniform seeds for each set of treatment were placed on moistened filter paper in a petri dish. Each treatment was further divided into two similar sets for representing germination behaviour on different temperature regimes (at ambient temperature $32-38.5^{\circ} \mathrm{C}$ and $25^{\circ} \mathrm{C}$ ) and was replicated thrice. The requisite growth conditions were maintained in a growth chamber having 8:16 hrs light/dark photoperiod. Seed germination was recorded daily and a seed was considered normally germinated when its radicle had emerged about $2 \mathrm{~mm}$ in length.

Speed of germination was calculated as:

$$
\frac{n_{1}}{d_{1}}+\frac{n_{2}-n_{1}}{d_{2}}+\frac{n_{3}-n_{2}}{d_{3}} \ldots n^{\text {th }} \text { day }
$$

Where, $n$ represents the number of germinated seeds, $d$ represents the number of days from start of the experiment, such as on day $1\left(d_{1}\right)$ up to $n^{\text {th }}=7^{\text {th }}$ day. After 7 days, final germination percentage, root length, shoot length and fresh weight of seedling 
were measured at both $25^{\circ} \mathrm{C}$ and ambient/room temperature conditions. Germination percentage was calculated by the following formula:

Germination percentage $=($ Number of germinated seeds $/$ Total number of seeds) $\times 100$

The seedlings were then dried in oven for 4-5 days at $65^{\circ} \mathrm{C}$ and their weights were subsequently measured to obtain a constant dry weight.

Statistical analysis : The data collected were analyzed using SAS Proc (SAS Institute, Inc., Cary, NC, 2009) for analysis of variance under completely randomized block design and the treatment means were compared by least significant difference (LSD) at 0.05 probability level.

\section{Results and Discussion}

Irrespective of priming, germination percentage was higher at ambient temperature than at $25^{\circ} \mathrm{C}$ (Table 1). Krzyzanowski and Delouche (2011) also reported that the optimal temperature zone for germination of cotton seed was $28^{\circ} \mathrm{C}$ to $30^{\circ} \mathrm{C}$ and any decrease from the optimal zone decreased the rate of germination. Priming with water clearly showed the positive effect on germination percentage with $43 \%$ and $34 \%$ increase over control (non-primed seeds) at ambient temperature and $25^{\circ} \mathrm{C}$, respectively (Fig. 3A). Similar results were observed in other crops such as wheat (Ghana and Schillinger, 2003), sunflower (Kaya et al., 2006) and corn (Vazirimehr et al., 2014). Tilki and Dirik (2007) also reported that Pinus brutia seed germination was lower at $15^{\circ} \mathrm{C}$ than $20^{\circ} \mathrm{C}$, regardless of stratification. Germination speed was higher at ambient temperature than at $25^{\circ} \mathrm{C}$ though the difference was nonsignificant. Interestingly, priming with water enhanced germination speed up to $61 \%$ and $67 \%$ than non-primed seeds at room temperature and $25^{\circ} \mathrm{C}$, respectively. This effect of hydropriming could be due to soaking before sowing (i.e., imbibition) which causes alterations in the metabolic reactions and accelerates the breakdown of metabolic reserves prior to radicle extrusion (Rezaee et al., 2015). It also facilitates active breakdown of metabolic reserves prior to radicle extrusion. Priming also increased the activity of anti-oxidative enzymes in germinating seeds of cotton (Asl and Taheri, 2012) and capsicum (Siri et al., 2013). Thus, hydro priming helps in early completion of initial phases of germination and protects the cell membrane from damage by reactive oxygen species and results in faster germination. This finding has a significant potential for application in North India where during cotton sowing months (May and June), daily maximum temperature often exceeds $40^{\circ} \mathrm{C}$ (Singh et al., 2013a) and offers a fairly good scope and opportunity to exploit the potential of tested priming agents, their quantity and duration of application for alleviation against high heat stress conditions.

Among seedling growth parameters, root length and shoot length increased significantly at ambient temperature $(2.51-4.14 \mathrm{~cm}$ and $3.24-3.52 \mathrm{~cm})$ than at $25^{\circ} \mathrm{C}(1.46-2.91 \mathrm{~cm}$ and $1.88-2.19 \mathrm{~cm})$. Highest root length $(4.14 \mathrm{~cm})$ was observed in hydroprimed seeds at ambient temperature, while minimum (1.46 $\mathrm{cm}$ ) was recorded in non-primed seeds at $25^{\circ} \mathrm{C}$. Hydropriming resulted in higher shoot length $(3.52 \mathrm{~cm})$ at ambient temperature, while at $25^{\circ} \mathrm{C}$ shoot length was higher in non-primed $(2.19 \mathrm{~cm})$ than primed seeds $(1.88 \mathrm{~cm})$. Temperature regimes exerted significant but soaking had non-significant effects on shoot length. Seedling fresh weight was highest $(0.232 \mathrm{~g})$ at ambient temperature in primed seeds (Table 1). However, variation in seedling fresh weight was non-significant for both the factors. Similar trend was observed for seedling dry weight with nonsignificant effect with relation to temperature as well as priming. Ahmadvand et al. (2012a) reported that hydroprimed seeds had increased seedling characteristics viz., root and shoot length and weight than non-primed ones. Enhanced seedling growth in hydro primed seeds might be attributed to their better efficiency for water absorption from growing media. The results of the present study are in confirmation with the study of Nejad (2013) who reported that metabolic activities of germination process commence much earlier in soaked seeds than radicle emergence. Consequently, increase in respiration, metabolism

Table 1 : Effect of temperature regimes and seed priming on seedling characteristics of cotton

\begin{tabular}{llllllll}
\hline Temperature & $\begin{array}{l}\text { Priming } \\
\text { Treatment }\end{array}$ & $\begin{array}{l}\text { Final germination } \\
\text { percentage }(\%)\end{array}$ & $\begin{array}{l}\text { Germination } \\
\text { speed }\end{array}$ & $\begin{array}{l}\text { Mean root } \\
\text { length }(\mathbf{c m})\end{array}$ & $\begin{array}{l}\text { Mean shoot } \\
\text { length }(\mathbf{c m})\end{array}$ & $\begin{array}{l}\text { Seedling fresh } \\
\text { weight }(\mathbf{g})\end{array}$ & $\begin{array}{l}\text { Seedling dry } \\
\text { weight }(\mathbf{g})\end{array}$ \\
\hline Ambient & & & & & & & \\
$\left(32-38.5^{\circ} \mathrm{C}\right)$ & Non-primed & 51.5 & 3.50 & 2.51 & 3.24 & 0.189 & 0.060 \\
& Primed & 90.9 & 9.00 & 4.14 & 3.52 & 0.232 & 0.064 \\
$25^{\circ} \mathrm{C}$ & Non-primed & 45.5 & 1.97 & 1.46 & 2.19 & 0.192 & 0.060 \\
& Primed & 69.7 & 6.06 & 2.91 & 1.88 & 0.193 & 0.066 \\
LSD $(0.05)$ & & $\mathrm{T}=\mathrm{NS}$ & $\mathrm{T}=\mathrm{NS}$ & $\mathrm{T}=1.1$ & $\mathrm{~T}=0.87$ & $\mathrm{~T}=\mathrm{NS}$ & $\mathrm{T}=\mathrm{NS}$ \\
& & $\mathrm{P}=\mathrm{NS}$ & $\mathrm{P}=3.78$ & $\mathrm{P}=1.1$ & $\mathrm{P}=\mathrm{NS}$ & $\mathrm{P}=\mathrm{NS}$ & $\mathrm{P}=\mathrm{NS}$ \\
& & $\mathrm{T} \times \mathrm{P}=\mathrm{NS}$ & $\mathrm{T} \times \mathrm{P}=\mathrm{NS}$ & $\mathrm{T} \times \mathrm{P}=\mathrm{NS}$ & $\mathrm{T} \times \mathrm{P}=\mathrm{NS}$ & $\mathrm{T} \times \mathrm{P}=\mathrm{NS}$ & $\mathrm{T} \times \mathrm{P}=\mathrm{NS}$ \\
\hline
\end{tabular}

$\mathrm{T}:$ Temperature, $\mathrm{P}:$ Priming, NS : Non-significant 

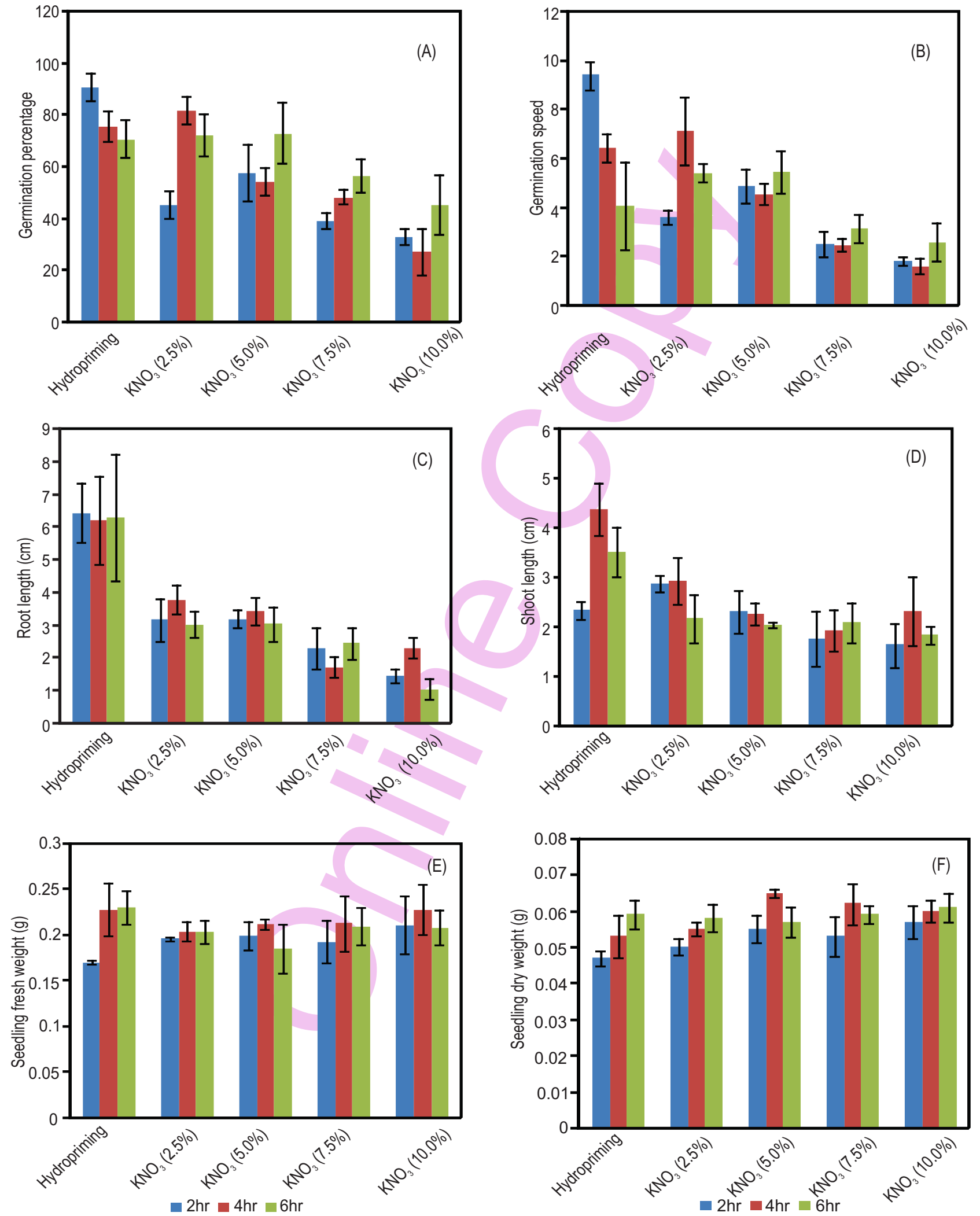

Fig. 1 : Effect of priming treatment and priming duration on (A) Final germination percentage; (B) Germination speed; (C) Root length; (D) Shoot length; (E) Seedling fresh weight and $(\mathrm{F})$ Seedling dry weight at ambient temperature $\left(32^{\circ}-38.5^{\circ} \mathrm{C}\right)$ 

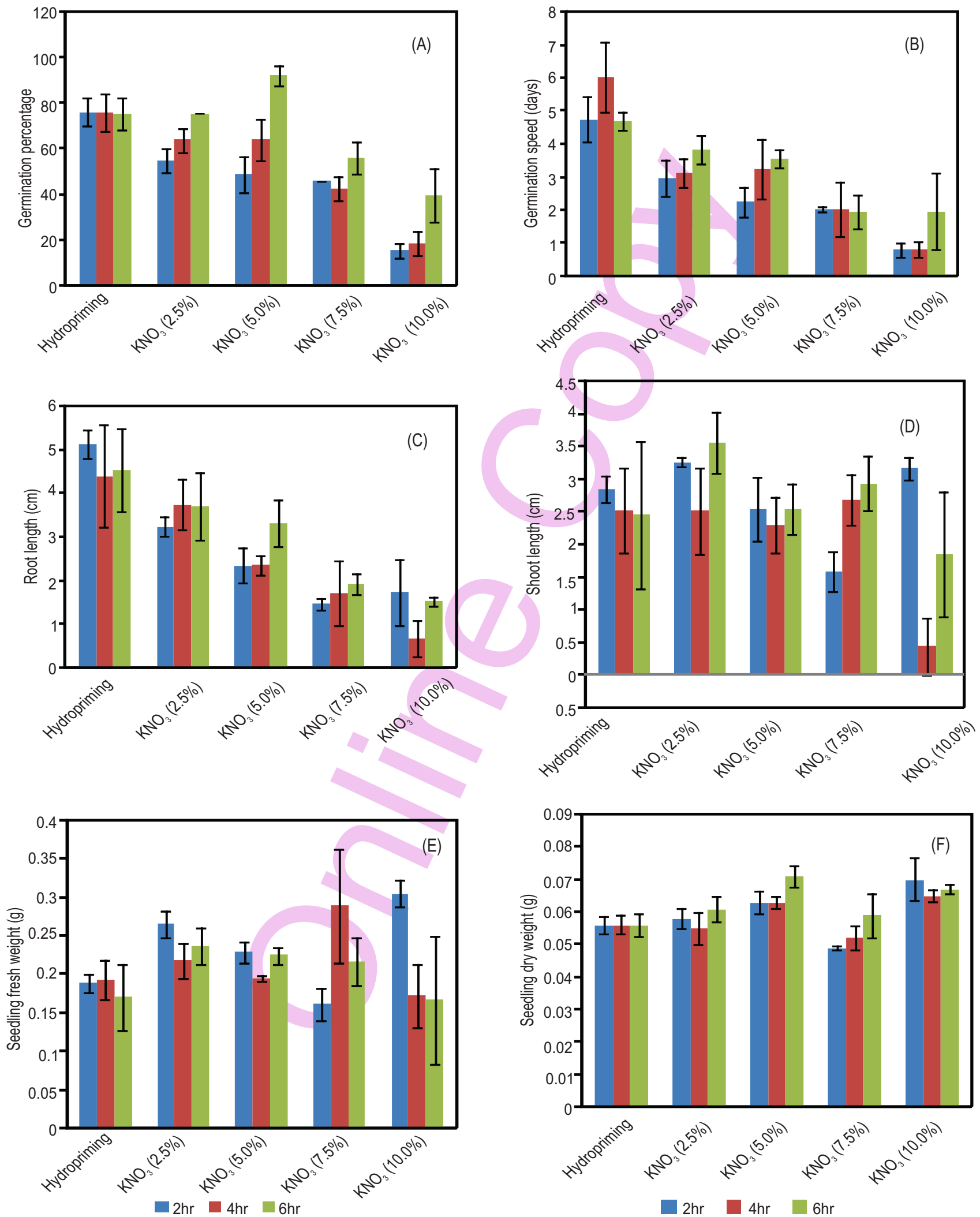

Fig. 2 : Effect of priming treatment and priming duration on (A) Final germination percentage; (B) Germination speed; (C) Root length; (D) Shoot length; (E) Seedling fresh weight and (F) Seedling dry weight at $25^{\circ} \mathrm{C}$ 
and water uptake rapidly after radicle protrusion results in resumption of cell division in embryonic tissues (Varier et al., 2010) and increased cell division leads to enhanced growth of seedling. Singh et al. (2013) reported that though heat stress tolerant germplasm can be of great utility in stressed climates, even then enhanced plant growth during critical and hot sowing period of cotton has vital significance which can be exploited to minimize seedling mortality in North India.

Seed priming with $\mathrm{KNO}_{3}$ at various concentrations and priming durations significantly affected final germination percentage at ambient temperature $\left(32-38.5^{\circ} \mathrm{C}\right)$. Among all priming treatments, hydro priming for $2 \mathrm{hrs}$ resulted in highest germination percentage $(90.9 \%)$ followed by control treatment (seeds hydro primed for $4 \mathrm{hrs}$ ) and $\mathrm{KNO}_{3}$ irrespective of varying concentrations (Fig. $1 \mathrm{~A}$ and $3 \mathrm{~B}$ ). Increasing concentration of $\mathrm{KNO}_{3}$ significantly decreased the final germination percentage having highest value with $2.5 \%(66.6 \%)$, followed by $5.0 \%$ $(61.7 \%), 7.5 \%(48.2 \%)$ and least with $10 \% \mathrm{KNO}_{3}(35.4 \%)$. A nonsignificant reduction in germination percentage was observed with increase in duration of hydropriming up to 4 hrs and 6 hrs. Contrarily, priming with $\mathrm{KNO}_{3}$ increased germination percent with prolonged duration of priming i.e. highest value with $6 \mathrm{hrs}(63.7 \%)$ and least with 2 hrs (53.3\%) of soaking. Pratap and Kumar (2010) depicted that length of stem and root; fresh as well as dry weight and number of lateral roots in black gram decreased with increase in concentration of solutes such as polyethylene glycol. So, hydro priming was found to be much effective than $\mathrm{KNO}_{3}$ for enhancing seed germination in cotton at ambient temperature. Furthermore, significantly higher germination speed was recorded in cotton seeds primed with water (6.63) in comparison to $5.0 \% \mathrm{KNO}_{3}$ (4.96), $7.5 \% \mathrm{KNO}_{3}(2.70)$ and $10 \% \mathrm{KNO}_{3}(2.00)$ primed seeds (Fig. 1B). It was also observed that with an increase in priming duration (2 hrs, 4 hrs and 6 hrs), there was non-significant reduction in germination speed under hydro priming but in case of $\mathrm{KNO}_{3}$ priming, germination speed increased at 6 hrs. Interaction between treatments and soaking time revealed that hydro priming with $2 \mathrm{hrs}$ priming duration was most effective for enhancing the rate of germination. Meena et al. (2013) found that seed hydropriming resulted in earlier seedling establishment, which contributed to better crop stand, increased tillering and higher grain yield in wheat than dry seed control. On the contrary, seed priming with $\mathrm{KNO}_{3}$ improved cotton emergence in green house as compared to hydropriming (Ahmadvand et al., 2012b). Under salt stressed sodic soils, $\mathrm{KNO}_{3}$ was found to be more effective for improving germination and wheat yield (Kalpana et al. 2013). $\mathrm{KNO}_{3}$ priming also improved shoot and root growth of cotton seedlings under drought stress (Shafiq et al., 2015). The priming induced increase in the rate of seed germination has been associated with the initiation of germination related processes, repair processes and increased levels of various free radical scavenging enzymes, such as superoxide dismutase, catalase and peroxidase (Vazirimehr et al., 2014). Another advantage is that primed cotton seeds can be easily stored under ambient conditions as enhancement resulted from priming is maintained for at least six months in case of hydro priming and about twelve months in osmo primed seeds (Toselli and Casenave, 2014).

Hydropriming per se significantly improved the root length as compared to different concentrations of $\mathrm{KNO}_{3}$ tested (Fig. 1C). Root length of hydro priming treatments for 2 and $6 \mathrm{hrs}$ were at par with control while $\mathrm{KNO}_{3}$ priming resulted in $47.4-74 \%$ reduction in root length than control. With increase in the concentration of $\mathrm{KNO}_{3}$, root length decreased significantly with minimum value under $10 \% \mathrm{KNO}_{3}(1.02 \mathrm{~cm})$ primed seeds. Priming duration had non-significant effect on root length and all the treatments were statistically at par to each other. Mean shoot length also followed the same trend as that of root length. Shoot length was maximum in control $(4.37 \mathrm{~cm})$ which was significantly higher than hydro priming (2 and $6 \mathrm{hrs}$ ), as well as $\mathrm{KNO}_{3}$ treatment (Fig. 1D). With increase in the concentration of $\mathrm{KNO}_{3}$, shoot length decreased up to $59.7 \%$ as compared to control. The increase in root length with hydro priming treatments might be due to induced nuclear replication in root tips of fresh seeds (Nejad, 2013). Moreover, enhancement of growth by soaking might be the consequence of hydrolysis of complex sugars into simple sugars that are readily utilized in the synthesis of auxins and proteins. Auxins help to soften cell walls and facilitate growth by increased cell division and proteins are utilized in the production of new tissues (Sabongari and Aliero, 2004). Basra et al. (2006) reported that hydro primed sunflower and wheat seeds could germinate faster and produced longer seedling under salinity stress as compared to untreated seeds. Mohejeri et al. (2015) also found hydro priming to be better than $\mathrm{KCl}$, while evaluating the effect of different priming treatments on emergence and growth of pinto bean. However, Nazir et al. (2014) reported $\mathrm{KNO}_{3}$ to be more effective than hydro priming for increasing plant height in cotton under salinity stress. Seedling fresh weight showed no particular trend with various treatments and time of soaking (Fig. 1E). There was nonsignificant variation in fresh weight of seedlings with hydro priming and $\mathrm{KNO}_{3}$ priming as evident from at par values of fresh weight with 6 hrs of hydro priming $(0.230 \mathrm{~g})$ and $4 \mathrm{hrs}$ of $\mathrm{KNO}_{3}$ priming $(0.228 \mathrm{~g})$. A non-significant difference was recorded in seedling dry weight of seeds hydro primed for $4 \mathrm{hrs}(0.053 \mathrm{~g})$ and $\mathrm{KNO}_{3}$ primed seeds $(0.054-0.059 \mathrm{~g})$ (Fig. 1F). These results suggest possibility of negative impact of $\mathrm{KNO}_{3}$ on seedling growth, though it necessitates for more elaborative studies to establish these basic findings.

Final germination percentage was significantly affected by various priming treatments and priming durations at $25^{\circ} \mathrm{C}$ (Fig. 2A). Final germination percentage in control (i.e. hydro primed seeds with 4 hrs of priming duration) was higher by 15$51 \%$ as compared to different concentrations of $\mathrm{KNO}_{3}$. With hydro priming at $2 \mathrm{hrs}, 4 \mathrm{hrs}$ and $6 \mathrm{hrs}$ of soaking, germination percentage remained in the range of $75-76 \%$. However in case of $\mathrm{KNO}_{3}$, increase in time of priming increased germination 


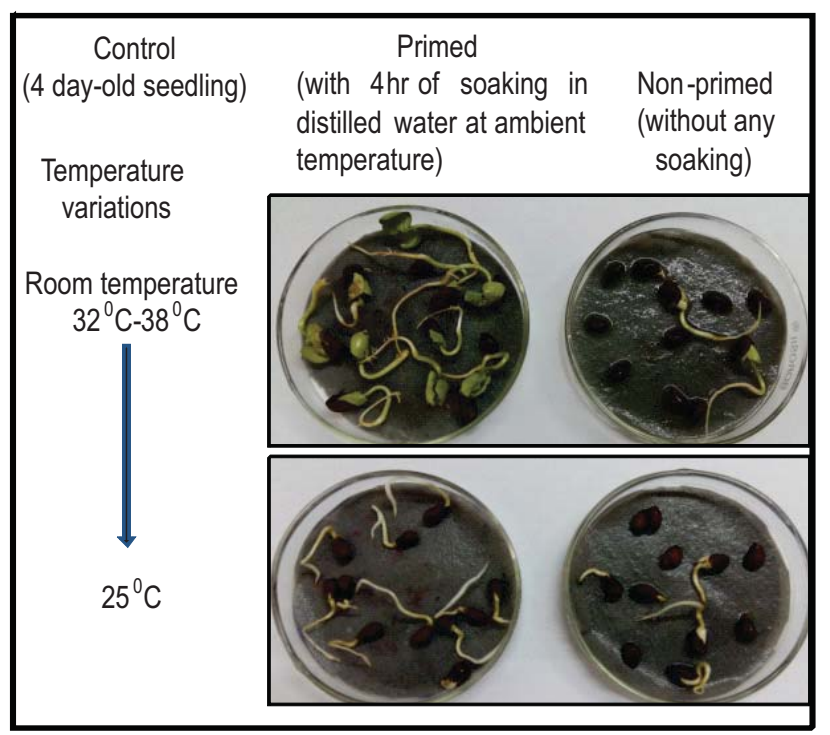

(A)

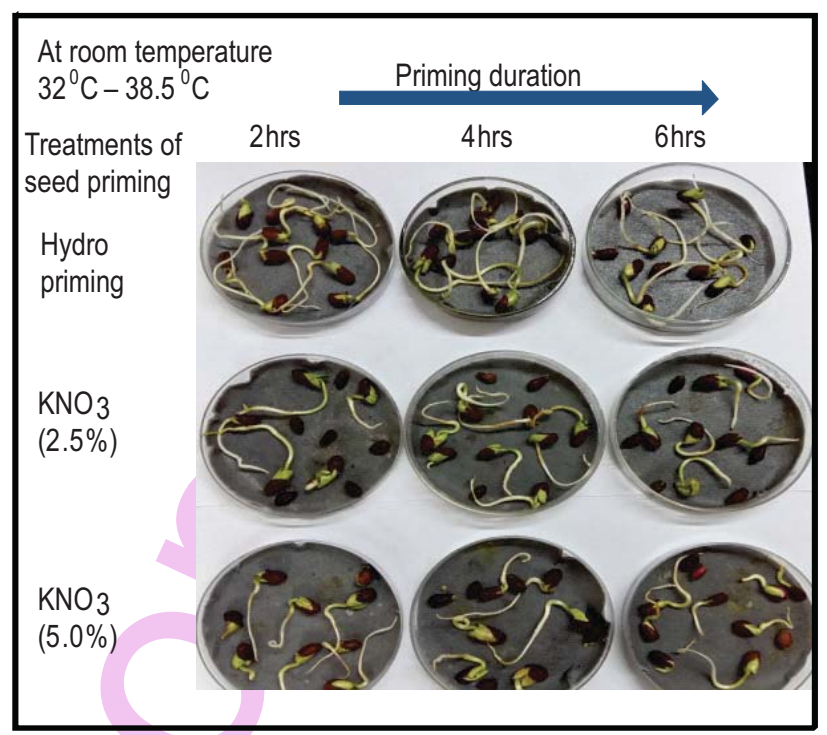

(B)

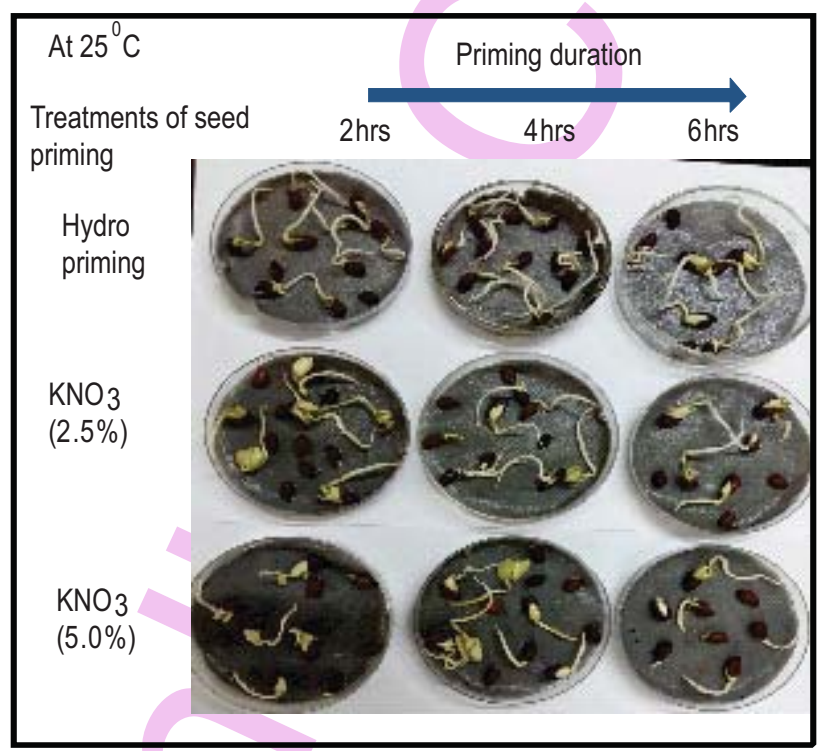

(C)

Fig. 3 : (A) Effect of temperature and priming on seedling characteristics of cotton; (B) Effect of priming treatments and priming duration on seedling characteristics of cotton at ambient temperature $\left(32-38.5^{\circ} \mathrm{C}\right) ;(\mathrm{C})$ Effect of priming treatments and priming duration on seeding characteristics of cotton at $25^{\circ} \mathrm{C}$

percent significantly in the following sequence: $2 \mathrm{hrs} \mathrm{(47.9 \% ),} 4$ hrs (52.7\%) and 6 hrs (67.3\%). Germination speed was lesser in $\mathrm{KNO}_{3}$ priming as compared to hydro primed seeds (Fig. 2B and $3 \mathrm{C}$ ). Increasing concentration of $\mathrm{KNO}_{3}$ decreased the germination speed as clearly evident from values i.e., $2.5 \%$ $\mathrm{KNO}_{3}(3.30), 5.0 \% \mathrm{KNO}_{3}(2.99), 7.5 \% \mathrm{KNO}_{3}(1.89), 10 \% \mathrm{KNO}_{3}$ (1.17). The present results are in corroboration with Sharma et al. (2013) who reported that hydro priming significantly increased the seed germination, seedling vigour and mean germination time in okra, however Ahmadvand et al. (2012b) and Dursun and Ekinci (2010) in contrast reported that seed treatment with potassium nitrate improved germination and germination rate in cotton and parsley, respectively. However, Anosheh et al. (2011) reported non-significant differences in germination between $\mathrm{KNO}_{3}$ primed and hydro primed maize seeds. Based on the results of the present study, as well as literature cited, the relevance of inherent genotypic resistance mechanism in cultivar(s) of a particular species to changes in seed priming response cannot be ignored apart from the role of plant species. 
The assessment of seedling growth in terms of root and shoot length revealed that root length $(4.68 \mathrm{~cm})$ was maximum in hydro primed seeds (Fig. 2C and 2D). The root length of seeds treated with different concentrations of $\mathrm{KNO}_{3}$ was significantly lesser than the hydro primed seeds and the root length decreased with increase in the concentration of $\mathrm{KNO}_{3}$, highest being at $2.5 \%$ $\mathrm{KNO}_{3}(3.56 \mathrm{~cm})$ and lowest at $10 \% \mathrm{KNO}_{3}(1.31 \mathrm{~cm})$. The effect of time of soaking on root length was non-significant for all treatments. Mean shoot length was also non-significantly affected by treatments, as well as time of soaking. A non-significant effect of various priming treatments was observed on seedling fresh weight (Fig. 2E). Seedling dry weight (Fig. 2F) was significantly higher in $5.0 \%$ and $10 \% \mathrm{KNO}_{3}$ treatments $(0.066 \mathrm{~g}$ and $0.067 \mathrm{~g})$ than control $(0.056 \mathrm{~g})$. The values of seedling dry weight were at par irrespective of priming durations. Lara et al. (2014) reported that $\mathrm{KNO}_{3}$ can lead to increased germination and seedling growth as it induces nitrate reductase enzyme which can convert nitrate to nitric oxide (NO, a hormone) which has positive impact on germination by breaking/reducing dormancy (Jacobsen et al., 2013). Contrarily, hydro priming treatment was found to be more effective for enhancing the seedling growth in the present study.

The findings of this study reveal better cotton seed germination at ambient temperature $\left(32-38.5^{\circ} \mathrm{C}\right)$ than $25^{\circ} \mathrm{C}$. Hydro priming was found best for improving germination behavior of cotton seeds. Thus, it can be used in cotton as an effective and economic technique under field conditions for synchronous germination and better seedling establishment.

\section{References}

Ahmadvand, G., F. Soleimani, B. Saadatian and M. Pouya: Effect of seed priming with potassium nitrate on germination and emergence traits of two soybean cultivars under salinity stress conditions. American-Eurasian. J. Agric. Environ. Sci., 12, 769-774 (2012a).

Ahmadvand, G., F. Soleimani, B. Saadatian and M. Pouya: Effect of seed priming on seed germination and seedling emergence of cotton under salinity stress. World Appl. Sci. J., 20, 1453-1458 (2012b).

Anosheh, H. P., H. Sadeghi and Y. Emam: Chemical priming with urea and $\mathrm{KNO}_{3}$ enhances maize hybrids (Zea mays L.) seed viability under abiotic stress. J. Crop Sci. Biotech., 14, 289-295 (2011).

Asl, M. B. A. and G. Taheri: Survey the effect of seed priming on germination and physiological indices of cotton khordad cultivar. Ann. Biol. Res., 3, 1003-1009 (2012).

Basra, S. M. A., L. Afzal, S. Anwar, M. Anwar-ul-haq, M. Shafq and K. Majeed: Alleviation of salinity stress by seed invigoration techniques in wheat (Triticum aestivum L.). Seed Technol., 28, 3646 (2006).

Cokkizgin, $H$. and $Y$. Bolek.: Priming treatments for improvement of germination and emergence of cotton seeds at low temperature. PI. Breeding Seed Sci., 71, 121-134 (2015).

Dorna, H., M. Jarosz, D. Szopinska, I. Szulc and A. Rosinska: Germination, vigour and health of primed Allium cepa L. seeds after storage. Acta Scientiarum Pololonorum Hortorum Cultus., 12, 43-58 (2013).

Dursun, A. and M. Ekinci: Effects of different priming treatments and priming durations on germination percentage of parsley
(Petroselinum crispum L.) seeds. Agric. Sci., 1, 17-23 (2010).

Ghana, S. G. and W.F. Schillinger: Seed priming winter wheat for germination, emergence and yield. Crop Sci., 43, 2135-2141 (2003).

Jacobsen, J. V., J.M. Barrero, T. Hughes, M. Julkowska, J.M. Taylor, Q. $X u$ and $F$. Gubler: Roles for blue light, jasmonate and nitric oxide in the regulation of dormancy and germination in wheat grain (Triticum aestivum L.). Planta, 238, 121-138 (2013).

Kader, M. A. and S.C. Jutzi: Temperature, osmotic pressure and seed treatments influence imbibition rates in sorghum seeds. J. Agron. Crop Sci., 188, 286-90 (2002).

Kalpana, A., H. Khan, A. K. Singh, K. N. Maurya, Mubeen, R.K. Yadava, Uma Singh and A.R. Gautam: Effect of different seed priming treatments on germination, growth, biochemical changes and yield of wheat varieties under sodic soil. Int. J. Sci. Res., 4, 306-310 (2013).

Kaya, M. D., G. Okcu, M. Atak, Y. Cikili and O. Kolsar: Seed treatments to overcome salt and drought stress during germination in sunflower (Helianthus annus L.). Eur. J. Agron., 24, 291-295 (2006).

Krzyzanowski, F. C. and J.C. Delouche: Germination of cotton seed in relation to temperature. Revista Brasileira de Sementes, 33, $543-$ 548(2011).

Lara, T. S., J.M.S Lira, A.C. Rodrigues, M. Rakocevic and A.A. Alvarenga: Potassium nitrate priming affects the activity of nitrate reductase and antioxidant enzymes in tomato germination. J. Agric. Sci., 6: $72-80$ (2014).

Meena, R. P., R. Sendhil, S.C. Tripathi, S. Chander, R.S. Chhokar and R.K. Sharma: Hydro-priming of seed improves the water use efficiency, grain yield and net economic returns of wheat under different moisture regimes. SAARC J. Agri., 11, 149-159 (2013).

Mohajeri, F., M. Taghvaei, M. Ramroudi and M. Galavi: The evaluation of the responses of pinto bean (Phaseolus vulgaris L.) seedling emergence and growth to different seed priming. J. Agric. Sci., 7, 235-242 (2015).

Nazir, M. S., A. Saad, Y. Anjum and W. Ahmad: Possibility of seed priming for good germination of cotton seed under salinity stress. J. Biol. Agric. Hlth., 4, 66-68 (2014).

Nejad, H. A.: The effects of seed priming techniques in improving germination and early seedling growth of Aeluropus macrostachys. Int. J. Adv. Biol. Biom. Res., 1, 86-95 (2013).

Pratap, V. and S.Y. Kumar: Impact of osmotic stress on seed germination and seedling growth in black gram (Phaseolus mungo). J. Env. Biol., 31,721-726 (2010).

Rezaee, S., M.M.R. Moghaddam and A.B. Bazrgar: Cotton seed germination as affected by salinity and priming. Indian $\mathrm{J}$. FundamentalAppl. Life Sci., 5, 312-318(2015).

Sabongari, S. and B.L. Aliero: Effects of soaking duration on germination and seedling growth of tomato (Lycopersicum esculentum Mill). Afr. J. Biotechnol., 3, 47-51 (2004).

SAS Institute Inc. (B. 9.2 Macro Languages: Reference Cary, NC: SAS Institute Inc., Copyright@ 2009 Cary, NC, USA(2009).

Shafiq, F., H. Batool, S.H. Raza and M. Hameed : Effect of potassium nitrate seed priming on allometry of drought-stressed cotton (Gossypium hirsutum L.). J. Crop Sci. Biotech., 18, 195-204 (2015).

Sharma, A. D., S.V.S. Rathore, K. Srinivasan and R. Tayagi: Comparison of various seed priming method for seed germination, seedling vigour and fruit yield in okra (Abelmoschus esculentus L. Moench). Scientia Hortic., 165, 75-81 (2013). 
Singh, K., P. Rathore and R.K. Gumber: Impact of varied levels and seed soaking period of water on seedling emergence sown with $B t$ cotton planter. J. Cotton Res. Dev., 29, 53-56 (2015).

Singh, K., S. Lokhande, B. Gajanayake, D. Brand, T. Wallace and K. Raja Reddy: Screening cotton cultivars for abiotic stress tolerance using reproductive and physiological parameters. In Proc. Beltwide Cotton Conf., San Antonio, Texas, USA, pp. 117-22 (2013).

Singh, K., H. Singh, K. Singh and P. Rathore: Effect of transplanting and seedling age on growth, yield attributes and seed cotton yield of $B t$ cotton. Indian J. Agric. Sci., 83, 508-13 (2013a).

Siri, B., K. Vichitphan, P. Kaewnaree, S. Vichitphan and P. Klanrit: Improvement of quality, membrane integrity and antioxidant systems in sweet pepper (Capsicum annuum Linn.) seeds affected by osmopriming. Aust. J. Crop Sci., 7, 2068-2073 (2013).
Tilaki, G. A. D., B. Behtari, M.A. Alizadeh and A.A. Jafari: Effect of seed priming on germination and seedling growth of Festuca arundinacea schreb and Agropyron desertorum (Fisch. ex link) J.A. Schultes. Environmental Magazine, 3, 323-330 (2010).

Tilki, F. and H. Dirik: Seed germination of three provenances of Pinus brutia (Ten.) as influenced by stratification, temperature and water stress. J. Env. Biol., 28, 133-136 (2007).

Toselli, M. E. and E.C. Casenave: Is the enhancement produced by priming in cotton seeds maintained during storage? Bragantia Campinas, 73, 372-376(2014).

Varier, A., A.K. Vari and M. Dadlani: The subcellular basis of seed priming. Curr. Sci., 99, 450-456 (2010).

Vazirimehr, M. R., H.R. Ganjali, K Rigi and A. Keshtehgar: Effect of seed priming on quantitative traits corn. Int. J. Pl. An Env. Sci., 4, 134140 (2014). 